\title{
FATHERS' PREDOMINANCE IN TRANSPORT ARRANGEMENTS FOR FAMILY TOURISM: E-CHAID-BASED PROFILING IN EAST ASIA
}

\author{
Yi-Fang Lan', Che-Jen $\mathrm{Su}^{2, *}$ \\ ${ }^{1}$ Graduate School of Tourism, Wakayama University, Wakayama City, Japan \\ ${ }^{2}$ Department of Restaurant, Hotel and Institutional Management, Fu Jen Catholic University, New Taipei City, \\ Taiwan \\ *E-mail of corresponding author: 040084@mail.fju.edu.tw
}

\section{Resume}

In decisions about transportation for family vacations, the distribution of the decision-making role between fathers and other family members is subject to characteristics of the society, the travel and the household. Therefore, the purpose of this study is to present a data-mining model that identifies the relative importance of those determining characteristics in predicting the probability of the father's predominance in transportation decisions for family vacations. By investigating cases across four East Asian societies and using exhaustive chi-square automatic identification detector analysis, it was found that the primary source of the family's income was the strongest predictor of the father-determined likelihood of decisions about vacation transportation. The results also suggested that the decision tree method is appropriate for targeting the father-predominant market of transportation in cross-societal contexts.

Available online: https://doi.org/10.26552/com.C.2021.4.G13-G24

\section{Article info}

Received 9 November 2020

Accepted 22 January 2021

Online 8 June 2021

\section{Keywords:}

decision tree,

East Asia,

Exhaustive Chi-square Automatic

Identification Detector (E-CHAID), family tourism,

Father-Determined Likelihood (FDL)

ISSN 1335-4205 (print version) ISSN 2585-7878 (online version)

\section{Introduction}

Transportation is considered to be an indispensable aspect of family tourism because participants' perceived risk of transport arrangements strongly affects their regard for travel information [1]. An important topic in family tourism research is the family's decisionmaking style for decisions about means of transport [2], but the extant research on the father's role in decision-making about the means of transportation for family vacations has produced contradictory results. For instance, Wang et al. [3] study in Taiwan found that the father and mother decided the means of transportation for family tours jointly, which agrees with the findings of a recent study in Spain [4] and Croatia [5]. Similar additional research results have supported a general argument that family vacation decisions are made jointly by the father and mother [6-8]. However, Kim et al. [9] from evidence in South Korea concluded that the father usually acted as the main decision-maker of transportation-related activities, thus supporting the general style of the family tourism decision-making in South Korea [10]. Their findings represent a broader contention that the father predominates in the decisions of transportation arrangements for family vacations in East Asia. A recent study by Cheng et al. [2] confirmed that fathers' predomination in determining the means of transportation for the family vacations prevailed across 25 societies. These various contradictory findings can be attributed to the choice of different respondents within the families accessed by the studies. Extant evidence on the roles that fathers play in the decision-making about the means of transportation for family vacations is rarely based on the data obtained from adolescent children [2], who, in fact, do possess the cognitive competence necessary to describe how the vacation decision roles are distributed within the family [11-14]. Perception bias can plague conclusions that are based on use of the traditional couple-reporting method to describe the distribution of roles in family vacation decision-making.

Indeed, the father's role in family vacations has rarely been studied [15]. A call has emerged for more exploration into fatherhood-related factors that will elaborate on family tourism from various perspectives, such as gender differentiation, dyadic consensus and parental style [16]. To address these issues in a general framework, it is advisable to conduct multilevel research that incorporates cultural and socioeconomic backgrounds at the societal level and travel-householdrelated characteristics at the individual level in the family decision-making processes for choosing tourist products $[2,7-8,14,17]$. However, no study to date has examined the predictive ability of variables at macro and micro levels regarding the father-determined 
likelihood (FDL) of family vacation decisions, such as transportation means, based on data mining across other societal contexts, such as East Asian societies. Thus, this study sought to apply the decision tree technique to develop a data-mining model of societal, travel and household attributes that could predict adolescents' perceptions of the FDL of decisions about transport means, using the binary categories of "yes" (i.e., by the father alone) or "no" (i.e., not (just) the father) for family travel. By investigating cases collected in China, Japan, South Korea and Taiwan, the overall cases of family vacation were segmented, from the rules generated by the model. In so doing, the relative importance of the predictor variables for the FDL of transport means was identified.

\section{Crossvergence across East Asia and family vacation decisions}

The concept of East Asia is also termed interchangeably as Confucian Asia in cross-societal studies, because societies of this cluster share Confucianism as a primary source of sociocultural influence on the formation of values [18]. Harmony is the underlying value of the Confucian family, school and workplace. To maintain harmony, family norms stress the division of roles in the husband-wife relationship, filial piety in the parent-child relationship and unequal priority between siblings [19-20]. Regardless of the value system that has evolved across the East Asian societies, through distinctive historical backgrounds and societal ideology, Confucianism has been widely used in analytical frameworks for research on issues of the Asian family [20-21], including family vacation decisionmaking [10, 22]. According to Confucian tradition, which emphasizes family-based interpersonal relationships in terms of communication and behavioural norms, clearly defined roles emerge for individuals in the family decision-making process.

At the societal level, individuals' behavioural variations across societal contexts can be explained by society's common value system, which is influenced by the two different categories of antecedents: culture and ideology. The two kinds of factors are advocated by convergence and divergence theories, respectively [2324]. Societal-convergence theory contests that a society's values are conditioned entirely by an ideological drive, such as the use of technology, the governance system, or the developmental orientation and that ideological drive furnishes a shared logic with which to shape similar norms. Conversely, the societal-divergence theory argues that individual-level values with respect to culture are preserved over time, regardless of changes in economy and technology [25-28]. Recently, the perspective of multilevel crossvergence, which entails societal-level divergence by culture and convergence by ideology and individual-level characteristics [29], has been introduced in an elaboration of family purchase decision-making under down-to-earth circumstances $[21,30]$. The multilevel crossvergence perspective was developed from the crossvergence theory [23, 31] and forms the foundation for reference frameworks in crosssocietal-context research. In response to that trend, it is worthwhile to extend the crossvergence perspective into family purchase decisions in order to take into account a multilevel theoretical foundation of societal backgrounds, such as sociocultural and ideological influences and individuals' features, on the formation of the family vacation decision-making.

The focus of this study is on four Eastern Asian societies: those of China, Japan, South Korea and Taiwan. These four societies share similar historical, geopolitical and geographical features but differ in their cultures and their development ideologies [10, 18-19, 21, 32]. In fact, their sociocultural and ideological differences could lead to significant variations in their FDL of decisions about family vacation transportation. Furthermore, it is argued against an assumption that all the East Asian consumers operate from shared similarities. Cultural and socioeconomic characteristics should be taken into consideration with travel- and household-related characteristics when one is trying to understand the roles that fathers play in deciding transport means for family vacations. Indeed, authors believe that the region's diversity is well represented by the four societies that were selected to represent East Asia. This study is innovative and should serve as groundwork for further studies on the FDL of transportation decisions for family travels in East Asia.

\section{Application of the decision tree methods in tourism studies}

A decision tree is a powerful data-mining approach for classification, prediction, interpretation and data manipulation and it has been used widely in behavioural research. For research designs, the application of a decision tree has two advantages that address the interpretability of results and the quality of data [33-34]. First, decision tree models simplify complex dependence relationships by dividing cases into distinctive subgroups, thus providing outputs that are clear to interpret. Second, a decision tree is a nonparametric approach without distributional assumptions. It needs no imputation to react to missing values and no transformation to respond to heavily skewed data. In addition, a decision tree is robust to outliers. The commonly used algorithms of a decision tree that are available in software are the Chi-square Automatic Interaction Detector (CHAID), the Classification and Regression Tree (CART) and the Quick, Unbiased, Efficient Statistical Tree (QUEST). In sum, these algorithms are distinctive in terms of their variable type, node splitting, tree pruning and splitting rules [33-34]. 
Table 1 Factors conditioning the FDL of transportation means for family vacations

\begin{tabular}{llll}
\hline label and source & description & \multicolumn{1}{l}{ category } \\
\hline sociocultural/ideological characteristics & & & \\
\hline SOC (Cheng et al., 2019; Yen et al., 2020) & society & (1)China, (2) Japan, (3) South Korea, (4) Taiwan \\
\hline travel characteristics & & (1) domestic vacation, (2) foreign vacation
\end{tabular}

In general, empirical comparisons have suggested that the CHAID-based models have been evaluated to be stably preferable to CART and QUEST [33, 35-37]. Moreover, the CHAID algorithm has been widely used to explore favourable segments of tourism market [38], profiles of tourist choice behaviours [39-40], tourist satisfaction [41]. The basic CHAID algorithm has also been modified as the Exhaustive CHAID (E-CHAID), which performs a more thorough merging and testing of the predictor variables. The remedies make E-CHAID an advantageous technique for tourism research. Even the use of CHAID-based algorithms contributes to tourist behaviour research, but no empirical study has heretofore attempted to use the decision tree analyses to explore the FDL of family vacation issues. Moreover, typical decision-tree research on tourist or travel behaviours rarely incorporates cultural factors into the model. Rules resulting from a single society tend to lack generalizable implications [42].

\section{Research significance}

This study's methodology extended and refined the use of decision tree analyses to examine decision-making about the means of transport in family tourism. First, rather than querying the fathers or mothers [43], the families' decision-making experiences were collected from adolescent family members, thus guaranteeing a more neutral approach than a lateral report from either of the parents would provide. In so doing, the risk of perception bias in the participants' descriptions of how family roles were distributed in vacation decisionmaking was greatly limited [2, 44]. Previous research also accepted that in addition to the parents, other family members who possess the cognitive competence are able to describe how decision roles are distributed in the family travel decision-making [11-13]. Furthermore, here cases were confined to families with adolescent(s) and in so doing the parent couples interacting with other family member(s) in a decision-making group was completely documented, [8, 12, 15, 45-48]. Third, these cases were drawn from four East Asian societies that have similarities yet are diverse in their sociocultural and ideological backgrounds and the sample size accommodated the conditions for applying a decision tree model. That sampling approach, with its cross-societal evidence, ensured that the results would have greater validity. Fourth, by using the E-CHAID technique, the East Asian tourist market of transportation for family travel in terms of fathers' predominance in making transport arrangements, was segmented according to the simultaneous predictive factors of society, travel and household. Therefore, this study clarifies the relative importance of condition variables at both the macro and micro levels in predicting whether the father alone is the decision maker about the means of transport for the family travel. It extends the application of decision tree analyses in tourist market segmentation to situations of cross-societal contexts, which have been highly emphasized for aiding the $r$ understanding of the growing market of family tourism in East Asia [44].

\section{Methods}

\subsection{Measures}

The dependent variable, the FDL of transportation means, was measured by rating it on a binary scale: 1 = yes (i.e., by the father alone), $2=$ no (i.e., not (just) the father). Table 1 summarizes the condition variables suggested by the literature review, with three types of conditions used for the E-CHAID analysis and their description and corresponding categories. They are (a) sociocultural/ideological characteristics-society (with SOC categorizing each case into China, Japan, South Korea and Taiwan); (b) travel characteristics-status of travel (with STA categorizing each case into domestic vacation or foreign vacation), duration of the trip, by number of days (with DUR categorizing each case into 1 2 days, 3 days, or 4 or more days) and travel group size 
(with GS categorizing cases into $2 \sim 3$ group members, 4 group members, or 5 or more group members); and (c) household characteristics - the number of children in the family (with $\mathrm{CN}$ categorizing each case into 1, 2, or 3 or more children) and the family's primary source of income (with INC categorizing each case into both parents, the father, the mother, or others). In addition, the respondents' demographics was investigated (i.e., gender, age, current stage of the family's life cycle, the highest educational level of the head of the household and the occupation of the head of the household). The authors' original questionnaire was produced in English and then the standard back-translation procedures were used to convert the questionnaire into each surveyed society's official language.

\subsection{Sample and procedures}

Total of 1,016 usable responses were collected from adolescents at campuses of senior high schools (i.e. the equivalent of grades 10 through 12 in the U.S. school system), from the four East Asia societies: China ( $n$ = 201), Japan $(n=262)$, South Korea $(n=268)$ and Taiwan $(n=285)$. An E-CHAID model was analyzed, consisting of six predictors, with the sample size of 1,016 and that yielded a sample size-to-condition variable ratio of 169.3 , which exceeded the minimum ratio of 150 [40]. The sampling criteria confined the age range of the participants (mean $=16.43$ years, s.d. $=0.91$ ) and thus attempted to avoid any significant variations in the family experience that the adolescent respondents' age-related transitions in decision-making competence would explain [8]. The participants were asked to recall a family decision that had included them and that had been about vacation during the past year. They were then asked to report the father-versus-other distribution in decisions about transportation for the vacation in their cohabiting family. Seventy percent of the participating adolescents were female, most $(87.4 \%)$ were currently living with both parents and a majority $(68.6 \%)$ came from a double-income family. Most respondents $(47.5 \%)$ came from families with two children. A majority (45.2\%) came from a family whose head of household was working in business or industry and a majority $(59.2 \%)$ came from a family in which the head of household was 35 years old or older and the youngest child was 0-17 year(s) old. The majority of the travel cases $(82.7 \%)$ were domestic and $66.9 \%$ of the vacations ranged from one to three days in duration. Overall, the vacations' means of transportation was determined by the father alone $(58.2 \%)$.

\subsection{Data analysis}

To induce rules that explained the FDL based on the condition variables, the IBM SPSS Decision Trees
20 program was used to analyse the data. The SOC was forced as the first predictor, to split the overall sample, because this research was cross-society oriented. The stopping criteria for FDL were set at 60 cases before and 30 cases after the division of the (sub)sample [41], at a significance level of 0.05 for predictor eligibility. The splitting process continued until either the split did not help to improve the predictive accuracy or a node contained fewer cases than the specified size.

\section{Results}

\subsection{Algorithm}

The decision tree structure that we constructed using the E-CHAID algorithm is shown in Figure 1. The top square of the tree diagram shows the distribution of the cases over the dependent variable, the categories of "yes" and "no." Below each of the squares are the predictor variables with the statistics for the split; the $p$-value, the Chi-square statistic and the degrees of freedom. The number and percentage of cases per category are given for each (group of) predictor category(ies). The model exhibited six layers of characteristics and ultimately led to eight end nodes that represented the final subgroups of the tree. The tree began with the top decision node (Node 0), with all 1,016 cases of the data set and the entire data set was then divided into two distinctive groups based on society: Node 1 (China) was dominated by "no" (59.2\%) and Node 2 (Japan, South Korea, Taiwan) was dominated by "yes' $(62.5 \%)$. Node 1 was further divided into two groups based on status of travel: Node 3 (domestic vacation) was dominated by "no" (51.9\%) and Node 4 (foreign vacation) was dominated by "no" (73.5\%). Node 3 was split into two groups, determined by the duration of the trip: Node 7 (3 days or fewer) was dominated by "yes" (69.6\%) and Node 8 (4 or more days) was dominated by "no" $(63.2 \%)$. In the same vein, the node at the right (Node 2) was broken into two groups by the family's main source of income: Node 5 (father, both parents, others) was dominated by "yes" $(65.8 \%)$ and Node 6 (mother) was dominated by "no" (83.6 \%). Then, Node 5 was divided into two groups based on status of travel: Node 9 (domestic vacation) was dominated by "yes" (69.3\%) and Node 10 (foreign vacation) was dominated by "no" (56.3\%). In addition, Node 9 was divided into two groups based on travel group size: Node 11 (2 3 group members) was dominated by "yes" $(51.8 \%)$ and Node 12 (more than 3 members) was dominated by "yes" $(72.8 \%)$. At the bottom of the tree, Node 11 was split into two groups on the basis of the number of children in the family: Node 13 ( 1 child) was dominated by "yes" $(71.7 \%)$ and Node 14 (more than one child) was dominated by "no" (66.7\%). The dendrogram shows that the rankings of predictors according to their ability to explain the variances of the FDL were INC $\left(\chi^{2}=53.43\right.$, Bonferroni adjusted $\left.p<.001\right)$, 


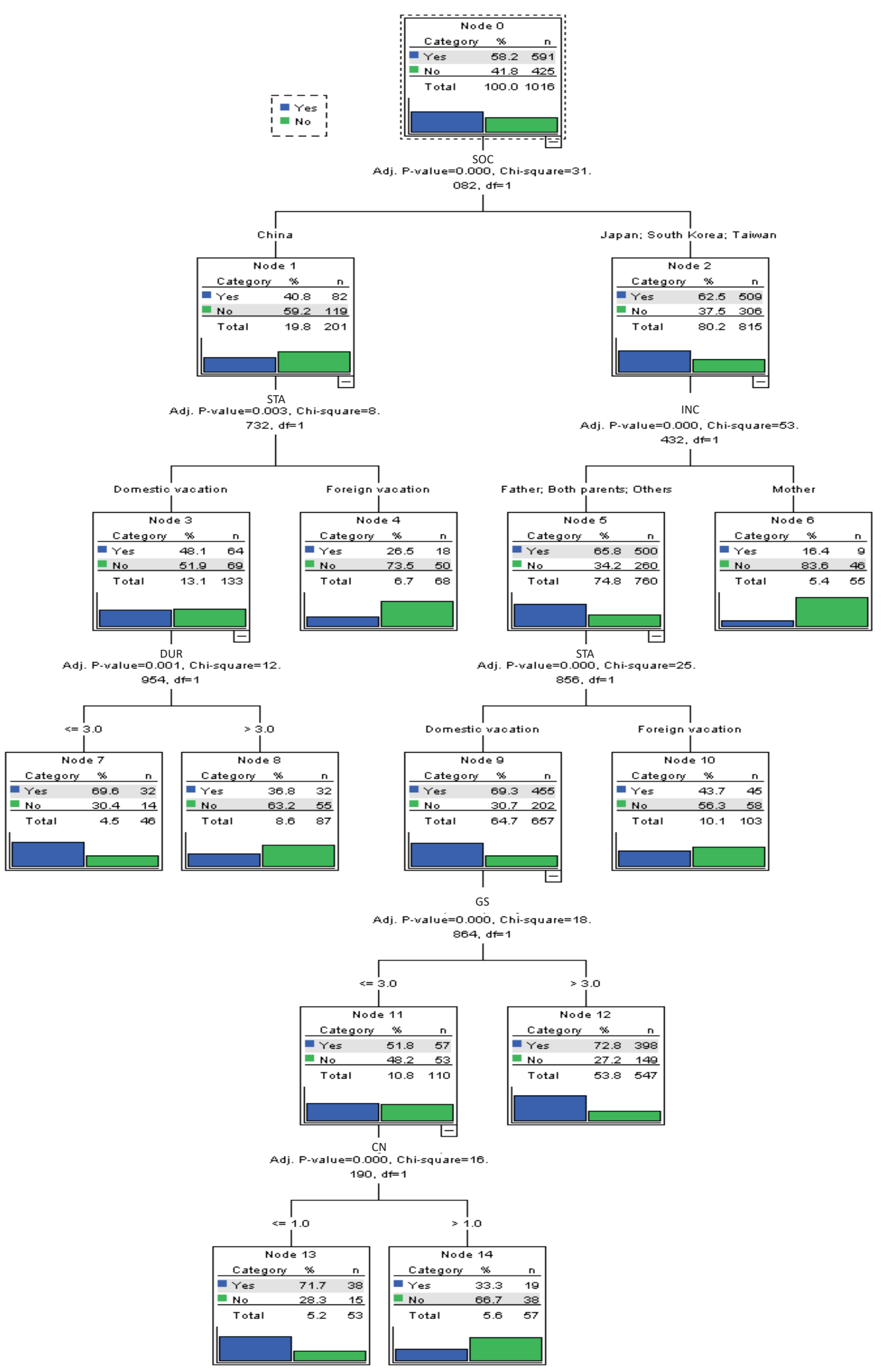

Figure 1 The E-CHAID dendrogram 
Table 2 FDL classification rules generated by the E-CHAID decision tree

\begin{tabular}{|c|c|c|}
\hline FDL & node & rule \\
\hline \multirow[t]{3}{*}{ yes } & 7 & IF SOC = "China" and STA = "domestic vacation" and DUR = "1 2" or "3" THEN FDL ="yes" \\
\hline & 13 & $\begin{array}{l}\text { IF SOC = "Japan" or "South Korea" or "Taiwan" and INC = "both parents" or "father" or "others" and STA = } \\
\text { "domestic vacation" and GS = "2 3" and CN = "1" THEN FDL ="yes" }\end{array}$ \\
\hline & 12 & $\begin{array}{l}\text { IF SOC = "Japan" or "South Korea" or "Taiwan" and INC = "both parents" or "father" or "others" and STA = } \\
\text { "domestic vacation" and GS = "4" or " } 5 \text { or more" THEN FDL ="yes" }\end{array}$ \\
\hline \multirow[t]{5}{*}{ no } & 8 & IF SOC = "China" and STA = "domestic vacation" and DUR = "4 or more" THEN FDL ="no" \\
\hline & 4 & IF SOC = "China" and STA = "foreign vacation" THEN FDL ="no" \\
\hline & 14 & $\begin{array}{l}\text { IF SOC = "Japan" or "South Korea" or "Taiwan" and INC = "both parents" or "father" or "others" and STA = } \\
\text { "domestic vacation" and GS = "2 3" and CN = "2" or "3 or more" THEN FDL ="no" }\end{array}$ \\
\hline & 10 & $\begin{array}{l}\text { IF SOC = "Japan" or "South Korea" or "Taiwan" and INC = "both parents" or "father" or "others" and STA = } \\
\text { "foreign vacation" THEN FDL ="no" }\end{array}$ \\
\hline & 6 & IF SOC = "Japan" or "South Korea" or "Taiwan" and INC = "mother" THEN FDL ="no" \\
\hline
\end{tabular}

Table 3 Gains for the end nodes and the end nodes' index scores and ranking

\begin{tabular}{ccccc}
\hline node & $\begin{array}{c}\text { segment size } \\
\text { (\% of overall sample size) }\end{array}$ & $\begin{array}{c}\text { number of 'yes' respondents } \\
\text { (\% of all 'yes' respondents) }\end{array}$ & $\begin{array}{c}\text { \% of 'yes' respondents to the } \\
\text { segment }\end{array}$ & $\begin{array}{c}\text { index } \\
\text { score }\end{array}$ \\
\hline 12 & $547(53.8)$ & $398(67.3)$ & 72.8 & 125 \\
13 & $53(5.2)$ & $38(6.4)$ & 69.6 & 123 \\
7 & $46(4.5)$ & $32(5.4)$ & 43.7 & 120 \\
10 & $103(10.1)$ & $45(7.6)$ & 36.8 & 75 \\
8 & $87(8.6)$ & $32(5.4)$ & 33.3 & 63 \\
14 & $57(5.6)$ & $19(3.2)$ & 26.5 & 57 \\
4 & $68(6.7)$ & $18(3.0)$ & 16.4 & 46 \\
6 & $55(5.4)$ & $9(1.5)$ & & 28 \\
\hline
\end{tabular}

SOC $\left(\chi^{2}=31.08\right.$, Bonferroni adjusted $\left.p<.001\right)$, STA $\left(\chi^{2}=25.86\right.$, Bonferroni adjusted $\left.p<.001\right)$, GS $\left(\chi^{2}=18.87\right.$, Bonferroni adjusted $p<.001), \mathrm{CN}\left(\chi^{2}=16.19\right.$, Bonferroni adjusted $p<.001)$ and DUR $\left(\chi^{2}=12.95\right.$, Bonferroni adjusted $p<.001$ ).

The classification rules generated by the decision tree are summarized in Table 2, following the path from each end node to the root node. The relationships between the condition variables and the percentage of the FDL associated with each variable were therefore determined.

Table 3 presents the gains for the end nodes and ranks the end nodes according to their index scores, which refer to the FDL rate of each segment relative to the overall FDL rate of $58.2 \%$. An index score exceeding 100 suggests that the corresponding end node had an above-average probability of predicting the FDL. By that criterion, three end nodes met the threshold. Node 12 had the highest index score, $125(72.8 \% / 58.2 \%)$, thus reflecting it having the highest probability of predicting FDL $(72.8 \%)$. Next were Node 13 , with an index score of $123(71.7 \% / 58.2 \%)$ and Node 7 with an index score of $120(69.6 \% / 58.2 \%)$. In contrast, an index score below 100 suggests that the corresponding end node had a below-average probability of predicting the FDL. Five end nodes were in that category that appeared to have a low probability of predicting the FDL. Node 6 scored the lowest, with $28(16.4 \% / 58.2 \%)$, thus reflecting its having the lowest probability of predicting the FDL (16.4 $\%)$. Next, also with low probabilities of predicting the FDL and each shown in comparison with the overall rate of $58.2 \%$, were Node $4(46=26.5 \% / 58.2 \%)$, Node 14 (57 $=33.3 \% / 58.2 \%)$, Node $8(63=36.8 \% / 58.2 \%)$ and Node $10(75=43.7 \% / 58.2 \%)$.

\subsection{Model performance}

The cumulative gain chart was used to evaluate the model's performance (see Figure 2). The horizontal axis plots the percentages, sorted based on the probability, from high to low and denotes the percentages of the test data set. The vertical axis records the percentages of the actual predicted values on the curved line. As Figure 2 shows, the line was an upward curve that rose steeply and then levelled off, thus suggesting that the tree model was acceptable for predicting the FDL.

The cumulative index chart was also used to check whether the tree model was appropriate for predicting the FDL. As is shown in Figure 3, the line started above $100 \%$, remained on a high plateau as it extended to the right and then gradually descended toward $100 \%$, thus confirming that the model was appropriate for predicting our target category of "yes." 


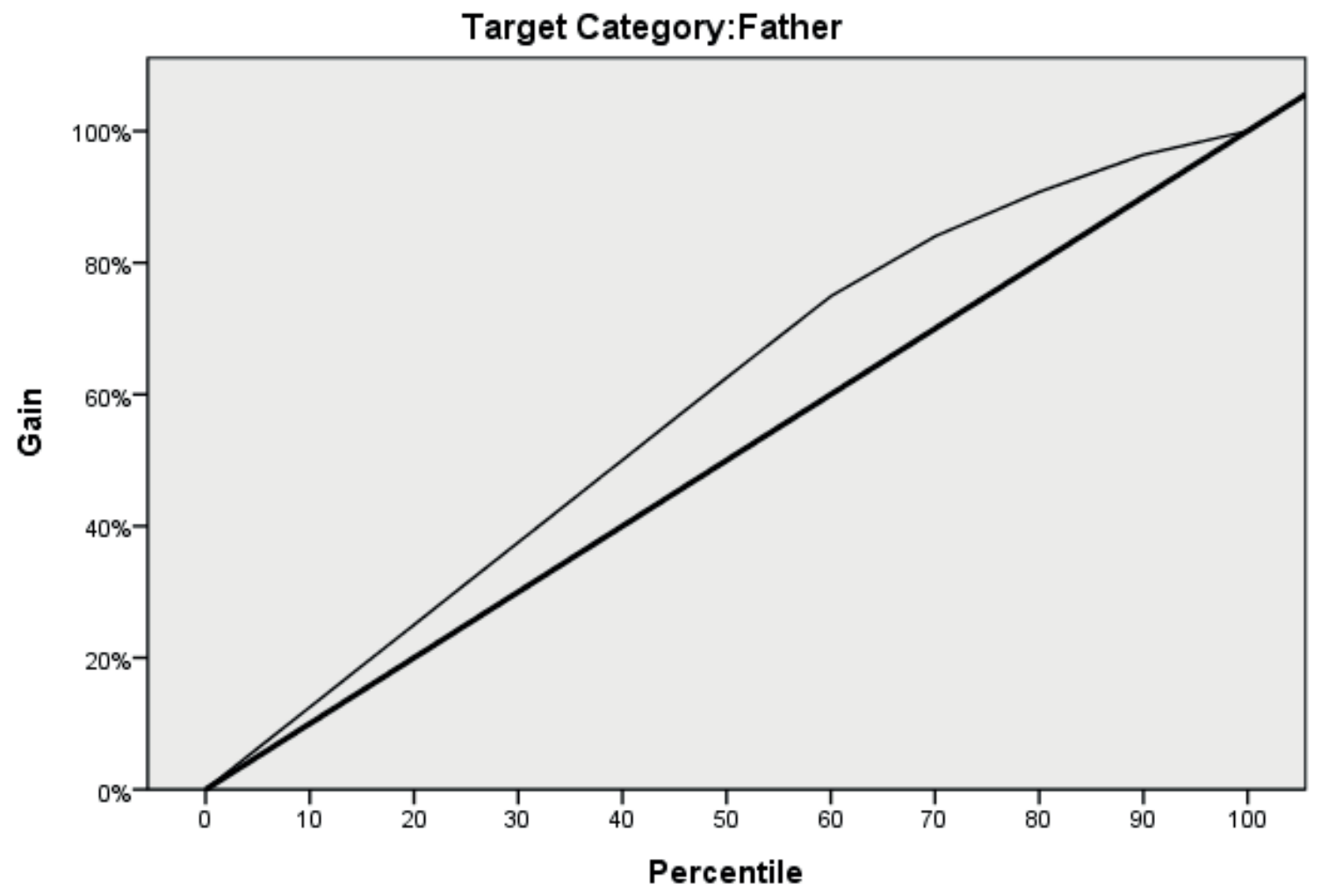

Growing Method:EXHAUSTIVE CHAID

Figure 2 Gain chart for the "Yes" category of FDL

Target Category:Father

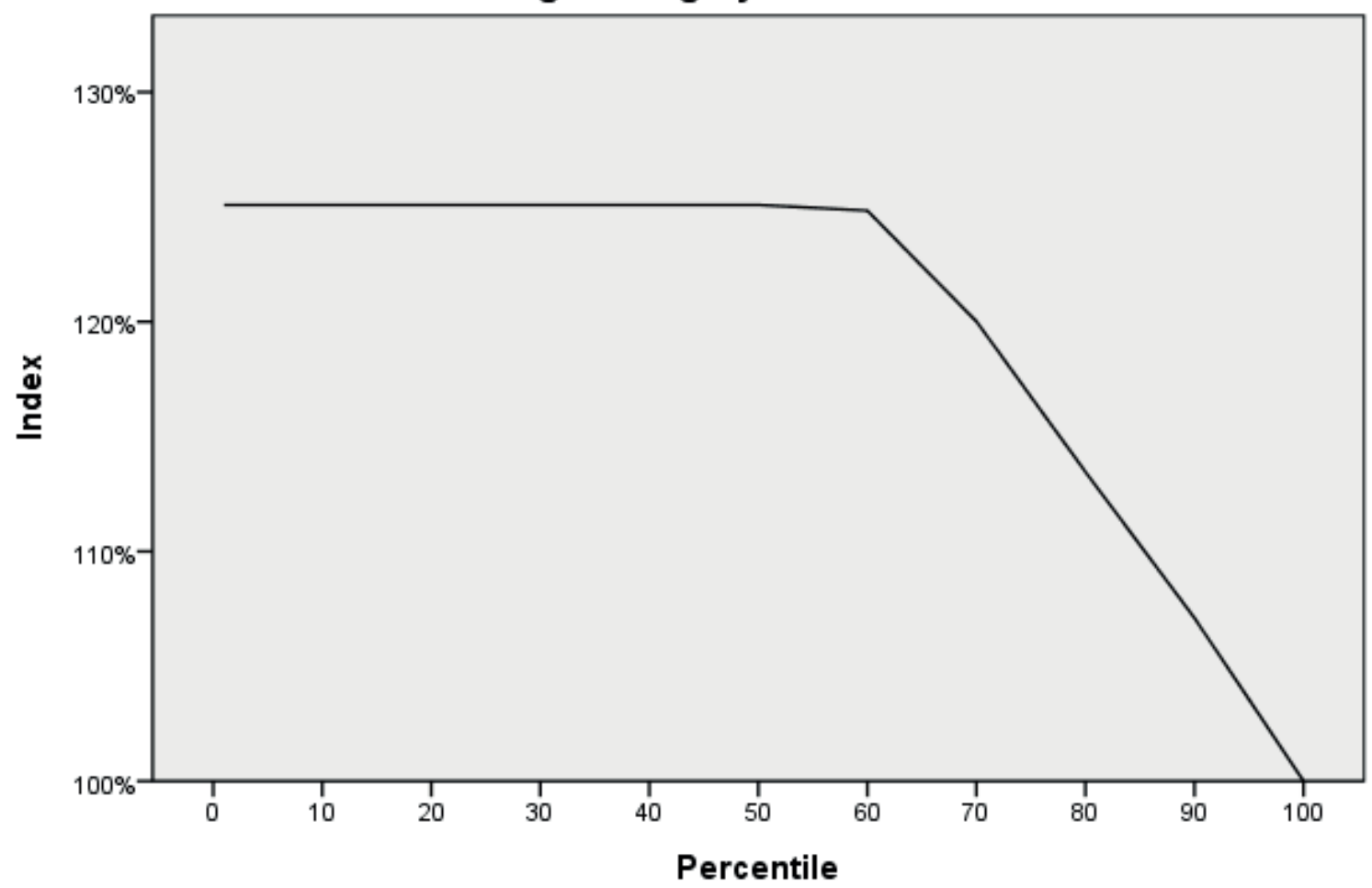

Growing Method:EXHAUSTIVE CHAID

Figure 3 Index chart for the "Yes" category of FDL 
Table 4 Confusion matrix and classification accuracy

\begin{tabular}{cccc}
\hline \multirow{2}{*}{ actual } & \multicolumn{3}{c}{ predicted } \\
\cline { 2 - 4 } & yes & no & correct \\
\hline yes & 468 & 123 & 79.2 \\
no & 178 & 247 & 58.1 \\
overall \% & 63.6 & 36.4 & 70.4 \\
\hline
\end{tabular}

Risk estimate $=.296 ;$ std. error $=.014$

The confusion matrix presented in Table 4 shows that the recall was $79.2 \%$ for predicting "yes" and was $58.1 \%$ for predicting "no," thus yielding a prediction accuracy of $70.4 \%$. In sum, our E-CHAID-generated model performed satisfactorily in elaborating on the condition variables of FDL.

\section{Discussion}

\subsection{Summary}

The presented study used the E-CHAID approach and the findings contribute to the relatively limited literature on the predominant role that fathers play in deciding the transportation means for the family travel. The results, derived from the 1,016 original cases from four societies in East Asia, provide a dendrogram that illustrates a set of rules based on the importance of various condition variables in predicting the FDL of decisions about transportation means for the family travel. Through following those rules, the study presents a profile of a viable set of segments, with distinctive sociocultural, ideological, travel and household characteristics, that are based on family tourism and can be used by the transportation market in East Asia. The decision tree model identified the rankings of several predictor variables for the FDL, according to the magnitude of the variables' effects and by using those predictor variables the model identified eight distinctive segments of cases of family travel.

\subsection{Contributions to theory}

Presented results align with the assertion that fathers tend to be powerful decision-makers about the transportation arrangements for family vacations and travel $[2,6,9]$. The evidence of fathers' predominance also adds to the rationale behind why the means of transportation is the least discussed by family members of all the sub-decisions for a family vacation [49]. For East Asian cases of family travel in general, transportation arrangements were most often determined by the father alone. That result echoes the understanding that the family role distribution for deciding aspects of family travel depends on the family members' relative involvement and their relative involvement in turn is shaped by their respective perceptions of knowledge of the issues and of relevant information [4, 8, 21, 30, 50 ] and by the gender-role division of responsibilities between spouses within the family [51]. In general, in families in East Asia, fathers are likely to take more responsibility for choosing the transportation means for family travel than mothers and children do, because of the fathers' personal interests and their opportunities to access information regarding transportation and their conformity to social expectations about the husband's role in the family, as well. However, the first decision tree splits showed that the Chinese group had more cases of "no", thus suggesting that China is distinctive in having a societal culture or development ideology that decreases fathers' predominance in deciding the means of transport for family travel, compared to Japan, South Korea and Taiwan, considered as a whole. This study confirms the advantage of having a synergetic perspective on values formation and evolution in crosssocietal studies on the family travel decision-making [23, 31, 52]. The use of composites of culture and societal effectiveness as predictors takes into account the similarities and differences of macro-level backgrounds across societies. Such an approach is expected to help refine the research methods and to explain family travel behaviour with greater validity $[2,14]$.

It is noteworthy that overall, regardless of the diversity of values formation and evolution across the four East Asian societies studied, the main source of household income, rather than the society, appeared to be the most important predictor of the fathers' predominance in vacation transportation decisions. This finding confirms that the primary source of the family's income determines the distribution of the decision-making power in planning family vacations [7-8, 48]. Taking the cases of Japan, South Korea and Taiwan as a group, in particular, showed that when mothers were the main source of family income, the fathers were not the predominant decision-maker, thus suggesting that the structure of economic power and reliance within the family, more than sociocultural or ideological forces, may shape the father-versus-other dominance style in decisions about transportation for family travel. Research also has shown that individuals' power over family purchase decisions decreases as their dependence on their family increases [21, 30]. This concept of dependence refers to the extent to which the individuals rely on the family to achieve their goals [53], such as financial reliance derived from their relationship with the family [54-55]. That economic support usually 
derives from the main income source for the family. The results suggested that for a Confucian region, such as East Asia [18], where male-oriented values underlie spousal roles in the family vacation decisions [10], the economic-reliance relationship appears to change the typical role distribution in spite of societal norms. In addition, it is found that fathers were a greater decisionmaker about transport means for domestic vacations than for the foreign ones (Node 3 vs Node 4; Node 9 vs Node 10); for medium-short vacations than for the long ones (Node 7 vs Node 8); and for one-child families than for families with two or more children (Node 13 vs Node 14). These findings confirm the speculation that family vacations that have high expenditures, long distances to the destination and long durations match the joint decision-making style between spouses [8]. Taken altogether, the presented model not only integrated multilevel variables in the segmentation and targeting of the family travel products market, but it elucidated the interactions among the multiple facets of family vacation market segmentation, as well. These findings offer East Asian evidence for application of an expanded crossvergence theory and demonstrate the theory's value in multilevel analyses of family vacation decisions.

\subsection{Managerial implications}

For marketing measures of family vacation products in East Asia, the results discussed above highlight the managerial implication that marketers, who wish to initiate a father-focused promotional strategy for entering the market of transportation for the family travel, should consider targeting Nodes 7, 12 and 13, rather than other segments, in their efforts to access and persuade fathers, because overall those three segments carried above-average likelihoods of father predominance in travel decision-making. It also implies that marketers need to take the significant condition variables into account in designing family vacation products and customizing communications programs that support fathers' decision-making about the means of transportation for the family vacations and prevent audience misunderstandings across societies. In addition, marketers could periodically update the database and amend the model to classify and predict the favourability of new cases expeditiously and identify additional contributing factors to the FDL of the means of transportation for the family vacation travels in East Asia. Such outputs could serve as references for examining the implementation of marketing strategies and revising them properly.

\subsection{Conclusions}

Results obtained in this study relate findings from other recent research [2, 56] to strongly suggest that although a general knowledge of history and culture is very important, such knowledge by itself is not sufficient to predict familial interpersonal dynamics. Further research is needed that will apply a multilevelcrossvergence perspective of regional, societal and individual influences to extend the understanding of the family decision-making about vacations. Such an approach will guide researchers to elaborate systematically on the effects that multilevel factors exert on the decision-making process about family vacations. Therefore, continuing the survey used in this study could be worthwhile in providing data on the decision-making roles of other issues, such as the family vacation's destination choice, so that further comparisons can be made. In addition, Confucianism-based norms of behaviour incorporate the distribution of roles of multiple generations within families [10, 16, 22]. Thus, the future endeavours would do well to expand vacation cases from the nuclear family to the multigenerational family, thereby considering grandparents and other seniors [57], so that one can capture a complete overview of the family tourism market in East Asia. Finally, this study focused on "means of transportation" decision that is a general description rather than on each mode of transportation (e.g., rented vehicle versus private vehicle or energyefficient mode versus eco-efficient mode) [5, 58-60]. Authors recommend that the future studies explore how fathers' predominance in arraying the modes of transportation is ruled by the condition variables.

\section{References}

[1] MASER, B., WEIERMAIR, K. Travel decision-making: from the vantage point of perceived risk and information preferences. Journal of Travel and Tourism Marketing [online]. 1998, 7(4), p. 107-121. ISSN 1054-8408, eISSN 1540-7306. Available from: https://doi.org/10.1300/J073v07n04_06

[2] CHENG, I. F., SU, C. J., LIAO, H. H., LORGNIER, N., LEBRUN, A. M., YEN, W. S., LAN, Y. F., HUANG, Y. Adolescents' perceptions of mother-father dominance in family vacation decisions: a 25-society study. Service Business [online]. 2019, 13(4), p. 755-778. ISSN 1862-8516, eISSN 1862-8508. Available from: https://doi.org/10.1007/s11628-019-00404-6

[3] WANG, K. C., HSIEH, A. T., YEH, Y. C., TSAI, C. W. Who is the decision-maker: The parents or the child in group package tours? Tourism Management [online]. 2004, 25(2), p. 183-194. ISSN 0261-5177. Available from: https://doi.org/10.1016/S0261-5177(03)00093-1 
[4] ROJAS-DE-GRACIA, M. M., ALARCON-URBISTONDO, P. Couple roles in sub-decisions on family vacations. Cornell Hospitality Quarterly [online]. 2018, 59(2), p. 160-173. ISSN 1938-9655, eISSN 1938-9663. Available from: https://doi.org/10.1177\%2F1938965517734941

[5] SRNEC, T., LONCARIC, D., PRODAN, M. P. Family vacation decision making process: evidence from Croatia. In: Faculty of Tourism and Hospitality Management in Opatija. Biennial International Congress Tourism \& Hospitality Industry 2016: proceedings. 2016. p. 432-445.

[6] JENKINS, R. L. Family vacation decision-making. Journal of Travel Research [online]. 1978, 16(4), p. 2-7. ISSN 0047-2875, eISSN 1552-6763. Available from: https://doi.org/10.1177\%2F004728757801600401

[7] KOC, E. The role of family members in the family holiday purchase decision-making process. International Journal of Hospitality \& Tourism Administration [online]. 2004, 5(2), p. 85-102. ISSN 1525-6480, eISSN 1525-6499. Available from: https://doi.org/10.1300/J149v05n02_05

[8] NANDA, D., HU, C., BAI, B. Exploring family roles in purchasing decisions during vacation planning: Review and discussions for future research. Journal of Travel and Tourism Marketing [online]. 2007, 20(3-4), p. 107-125. ISSN 1054-8408, eISSN 1540-7306. Available from: https://doi.org/10.1300/J073v20n03_08

[9] KIM, S. S., CHOI, S., AGRUSA, J., WANG, K. C., KIM, Y. The role of family decision makers in festival tourism. International Journal of Hospitality Management [online]. 2010, 29(2), p. 308-318. ISSN 0278-4319. Available from: https://doi.org/10.1016/j.ijhm.2009.10.004

[10] YANG, M. J. H., KHOO-LATTIMORE, C., YANG, E. C. L. Three generations on a holiday: Exploring the influence of Neo-Confucian values on Korean multigenerational family vacation decision making. Tourism Management [online]. 2020, 78, 104076. ISSN 0261-5177. Available from: https://doi.org/10.1016/j.tourman.2020.104076

[11] KOZAK, M., KARADAG, L. Who influences aspects of family decision making? International Journal of Culture, Tourism and Hospitality Research [online]. 2012, 6(1), p. 8-20. ISSN 1750-6182. Available from: https://doi.org/10.1108/17506181211206216

[12] SPIERS, M. Families with adolescents: vacation decision making [online]. PhD thesis. Melbourne, Australia: Victoria University, 2017. Available from: http://vuir.vu.edu.au/id/eprint/33206

[13] SU, C. J., LIAO, H. H., LORGNIER, N., YEN, W. S., BOUCHET, P., HIROOKA, Y., JALLOULI, R., ROBERTSLOMBARD, M., LAN, Y. F. Measuring adolescent influence tactics with parents in family vacation decisions: A comparable scale across 19 societies. SAGE Open [online]. 2019, 9(1), 209. ISSN 2158-2440, eISSN 2158-2440. Available from: https://doi.org/10.1177/21582 44019835950

[14] YEN, W. S., SU, C. J., LAN, Y. F., MAZUREK, M., KOSMACZEWSKA, J., SVAGZDIENE, B., CHERENKOV, V. Adolescents' use of influence tactics with parents in family travel decision making: a cross-societal comparison in Eastern Europe. The Social Science Journal [online]. 2020, in press. ISSN 0362-3319, eISSN 1873-5355. Available from: https://doi.org/10.1080/03623319.2020.1745519

[15] SCHANZEL, H. The inclusion of fathers, children and the whole family group in tourism research on families. In: Family tourism: multidisciplinary perspectives. SCHANZEL, H., YEOMAN, I., BACKER, E. (eds.). Bristol, UK: Channel View Publications, 2012. ISBN 9781845413262, p. 67-80.

[16] LI, M., LEHTO, X., LI, H. 40 years of family tourism research: Bibliometric analysis and remaining issues. Journal of China Tourism Research [online]. 2020, 16(1), p. 1-22. ISSN 1938-8160, eISSN 1938-8179. Available from: https://doi.org/10.1080/19388160.2020.1733337

[17] THERKELSEN, A. Deciding on family holidays: Role distribution and strategies in use. Journal of Travel and Tourism Marketing [online]. 2010, 27(8), p. 765-779. ISSN 1054-8408, eISSN 1540-7306. Available from: https://doi.org/10.1080/10548408.2010.526895

[18] GUPTA, V., HANGES, P. J., DORFMAN, P. Cultural clusters: Methodology and findings. Journal of World Business [online]. 2002, 37(1), p. 11-15. ISSN 1090-9516. Available from: https://doi.org/10.1016/S10909516(01)00070-0

[19] HOFSTEDE, G., HOFSTEDE, G. J., MINKOV, M. Cultures and organizations, software of the mind. Intercultural cooperation and its importance for survival. 3. ed. NY, New York: McGraw-Hill, 2010. ISBN 978-0-07-177015-6.

[20] PARK, M., CHESLA, C. Revisiting Confucianism as a conceptual framework for Asian family study. Journal of Family Nursing [online]. 2007, 13(3), p. 293-311. ISSN 1074-8407, eISSN 1552-549X. Available from: https://doi.org/10.1177\%2F1074840707304400

[21] SU, C. J., WANG, S. A cross-cultural study of East Asian adolescents' influence in family purchase decisions. Journal of Global Business and Technology [online]. 2010, 6(1), p. 52-67. ISSN 1553-5495, eISSN 2616-2733.

[22] WU, M. Y., WALL, G. Chinese research on family tourism: Review and research implications. Journal of China Tourism Research [online]. 2016, 12(3-4), p. 274-290. ISSN 1938-8160, eISSN 1938-8179. Available from: https://doi.org/10.1080/19388160.2016.1276873

[23] RALSTON, D. A. The crossvergence perspective: Reflections and projections. Journal of International Business Studies [online]. 2008, 39(1), p. 27-40. ISSN 0047-2506, eISSN 1478-6990. Available from: https://doi.org/10.1057/ palgrave.jibs. 8400333 
[24] REISINGER, Y., CROTTS, J. C. Applying Hofstede's national culture measures in tourism research: illuminating issues of divergence and convergence. Journal of Travel Research [online]. 2010, 49(2), p. 153-164. ISSN 0047-2875, eISSN 1552-6763. Available from: https://doi.org/10.1177\%2F0047287509336473

[25] BUDHWAR, P. S., VARMA, A., PATEL, C. Convergence-divergence of HRM in the Asia-Pacific: Context-specific analysis and future research agenda. Human Resource Management Review [online]. 2016, 26(4), p. 311-326. ISSN 1053-4822. Available from: https://doi.org/10.1016/j.hrmr.2016.04.004

[26] DUNPHY, D. Convergence/divergence: a temporal review of the Japanese enterprise and its management. Academy of Management Review [online]. 1987, 12(3), p. 445-459. ISSN 0363-7425, eISSN 1930-3807. Available from: https://doi.org/10.5465/amr.1987.4306560

[27] GUO, C. Cultural convergence, divergence and crossvergence. Vol. 6: International management [online]. In: Wiley encyclopaedia of management. COOPER, C. L., VODOSEK, M., HARTOG, D. N., MCNETT, J. M. (eds.). Hoboken, NJ: John Wiley \& Sons, 2015. ISBN 9781118785317. Available from: https://doi.org/10.1002/9781118785317. weom060049

[28] RICKS, D. A., TOYNE, B., MARTINEZ, Z. Recent developments in international management research. Journal of Management [online]. 1990, 16(2), p. 219-253. ISSN 0149-2063, eISSN 1557-1211. Available from: https://doi.org/10.1177\%2F014920639001600202

[29] RALSTON, D. A., EGRI, C. P., CASADO, T., FU, P., WANGENHEIM, F. The impact of life stage and societal culture on subordinate influence ethics: a study of Brazil, China, Germany and the US. Journal of International Management [online]. 2009, 15(4), p. 374-386. ISSN 1075-4253. Available from: https://doi.org/10.1016/j. intman.2009.02.004

[30] SU, C. J. The moderating role of composites of cultural values in predicting adolescents' influence on family purchase decisions: A study of Asian cases. African Journal of Business Management [online]. 2011, 5(15), p. 6058-6071. ISSN 1993-8233. Available from: https://doi.10.5897/AJBM10.225

[31] RALSTON, D. A., GUSTAFSON, D. J., CHEUNG, F. M., TERPSTRA, R. H. Differences in managerial values: A study of US, Hong Kong and PRC managers. Journal of International Business Studies [online]. 1993, 24(2), p. 249-275. ISSN 0047-2506, eISSN 1478-6990. Available from: https://doi.org/10.1057/palgrave.jibs.8490232

[32] XU, X., SONG, L. Export similarity and the pattern of East Asian development. In: China in the global economy. LLOYD, P. J., ZHANG, X. (eds.), Cheltenham, UK: Edward Elgar Publishing, 2000. ISBN 9781840642902 , p. $145-164$.

[33] LIN, C. L., FAN, C. L. Evaluation of CART, CHAID and QUEST algorithms: A case study of construction defects in Taiwan. Journal of Asian Architecture and Building Engineering [online]. 2019, 18(6), p. 539-553. ISSN 13467581, eISSN 1347-2852. Available from: https://doi.org/10.1080/13467581.2019.1696203

[34] SONG, Y. Y., LU, Y. Decision tree methods: applications for classification and prediction. Shanghai Archives of Psychiatry [online]. 2015, 27(2), p. 130-135. ISSN 1002-0829. Available from: https://doi.org/ 10.11919/j.issn.10020829.215044

[35] CHOU, J. S. Comparison of multi-label classification models to forecast project dispute resolutions. Expert Systems with Applications [online]. 2012, 39(11), p. 10202-10211. ISSN 0957-4174. Available from: https://doi.org/10.1016/j.eswa.2012.02.103

[36] JAN, C. L. An effective financial statements fraud detection model for the sustainable development of financial markets: Evidence from Taiwan. Sustainability [online]. 2018, 10(2), 513. eISSN 2071-1050. Available from: https://doi.org/10.3390/su10020513

[37] SUT, N., SIMSEK, O. Comparison of regression tree data mining methods for prediction of mortality in head injury. Expert Systems with Applications [online]. 2011, 38(12), p. 15534-15539. ISSN 0957-4174. Available from: https://doi.org/10.1016/j.eswa.2011.06.006

[38] HSU, C. H., KANG, S. K. CHAID-based segmentation: international visitors' trip characteristics and perceptions. Journal of Travel Research [online]. 2007, 46(2), p. 207-216. ISSN 0047-2875, eISSN 1552-6763. Available from: https://doi.org/10.1177\%2F0047287507299571

[39] BARGEMAN, A., JOH, C. H., TIMMERMANS, H., VAN DER WAERDEN, P. Correlates of tourist vacation behavior: a combination of CHAID and loglinear logit analysis. Tourism Analysis. 1999, 4(2), p. 83-93. ISSN 1083-5423, eISSN 1943-3999.

[40] VAN MIDDELKOOP, M., BORGERS, A., TIMMERMANS, H. Inducing heuristic principles of tourist choice of travel mode: A rule-based approach. Journal of Travel Research [online]. 2003, 42(1), p. 75-83. ISSN 0047-2875, eISSN 1552-6763. Available from: https://doi.org/10.1177\%2F0047287503254116

[41] ROJAS-DE-GRACIA, M. M., ALARCON-URBISTONDO, P. Couple's decision-making process and their satisfaction with the tourist destination. Journal of Travel Research [online]. 2019, 58(5), p. 824-836. ISSN 0047-2875, eISSN 1552-6763. Available from: https://doi.org/10.1177\%2F0047287518785052

[42] RAMASWAMI, M., BHASKARAN, R. A CHAID based performance prediction model in educational data mining. International Journal of Computer Science Issues. 2010, 7(1), p. 10-18. ISSN 1694-0814, eISSN 1694-0784. 
[43] ZALATAN, A. Wives involvement in tourism decision processes. Annals of Tourism Research [online]. 1998, 25(4), p. 890-903. ISSN 0160-7383. Available from: https://doi.org/10.1016/S0160-7383(98)00038-3

[44] KHOO-LATTIMORE, C., PRAYAG, G., CHEAH, B. L. Kids on board: Exploring the choice process and vacation needs of Asian parents with young children in resort hotels. Journal of Hospitality Marketing and Management [online]. 2015, 24(5), p. 511-531. ISSN 1936-8623, eISSN 1936-8631. Available from: https://doi.org/10.1080/193 68623.2014 .914862

[45] CHAUDHARY, M. Family decision - making in emerging economies. International Journal of Business and Globalisation [online]. 2015, 14(3), p. 310-320. ISSN 1753-3627, eISSN 1753-3635. Available from: https://doi.org/10.1504/IJBG.2015.068630

[46] CHAUDHARY, M., GUPTA, A. Children's influence in family buying process in India. Young Consumers [online]. 2012, 13(2), p. 161-175. ISSN 1747-3616. Available from: https://doi.org/10.1108/17473611211233512

[47] GHOUSE, S. M., CHAUDHARY, M., DURRAH, O. Socialization and the buying behaviour of the Arab child consumers: insights from Oman. Journal of Islamic Marketing [online]. 2019, 11(2), p. 461-478. ISSN 1759-0833. Available from: https://doi.org/10.1108/JIMA-09-2018-0176

[48] FILIATRAULT, P., RITCHIE, J. R. B. Joint purchasing decisions: A comparison of influence structure in family and couple decision making units. Journal of Consumer Research [online]. 1980, 7(2), p. 131-140. ISSN 0093-5301, eISSN 1537-5277. Available from: https://doi.org/10.1086/208802

[49] BRONNER, F., DE HOOG, R. A new perspective on tourist information search: discussion in couples as the context. International Journal of Culture, Tourism and Hospitality Research [online]. 2011, 5(2), p. 128-143. ISSN 750-6182. Available from: http://dx.doi.org/10.1108/17506181111139555

[50] LIEN, N. H., WESTBERG, K., STAVROS, C., ROBINSON, L. J. Family decision-making in an emerging market: Tensions with tradition. Journal of Business Research [online]. 2018, 86(C), p. 479-489. ISSN 0148-2963. Available from: https://doi.org/10.1016/j.jbusres.2017.09.003

[51] PENZ, E., KIRCHLER, E. Sex-role specialization in a transforming market: Empirical evidence from Vietnamese middle-class households. Journal of Macromarketing [online]. 2012, 32(1), p. 61-73. ISSN 0276-1467, eISSN 1552-6534. Available from: https://doi.org/10.1177\%2F0276146711421787

[52] RALSTON, D. A., HOLT, D. H., TERPSTRA, R. H., KAI-CHENG, Y. The impact of natural culture and economic ideology on managerial work values: A study of the United States, Russia, Japan and China. Journal of International Business Studies [online]. 1997, 28(1), p. 177-208. ISSN 0047-2506, eISSN 1478-6990. Available from: https://doi.org/10.1057/palgrave.jibs.8490097

[53] KEITH, J. E., JACKSON JR, D. W., CROSBY, L. A. Effects of alternative types of influence strategies under different channel dependence structures. Journal of Marketing [online]. 1990, 54(3), p. 30-41. ISSN 0022-2429, eISSN 1547-7185. Available from: https://doi.org/10.1177\%2F002224299005400303

[54] BEATTY, S. E., TALPADE, S. Adolescent influence in family decision making: A replication with extension. Journal of Consumer Research [online]. 1994, 21(2), p. 332-341. ISSN 0093-5301, eISSN 1537-5277. Available from: https://doi.org/10.1086/209401

[55] FOXMAN, E. R., TANSUHAJ, P. S., EKSTROM, K. M. Adolescents' influence in family purchase decisions: A socialization perspective. Journal of Business Research [online]. 1989, 18(2), p. 159-172. ISSN 0148-2963. Available from: https://doi.org/10.1016/0148-2963(89)90033-7

[56] RALSTON, D. A., EGRI, C. P., KARAM, C. M., LI, Y., FU, P. P. Changes in work values across the regions of China. Asia Pacific Journal of Management [online]. 2018, 35(1), p. 145-179. ISSN 0217-4561, eISSN $1572-9958$. Available from: https://doi.org/10.1007/s10490-017-9519-y

[57] WANG, K. C., CHEN, J. S., CHOU, S. H. Senior tourists' purchasing decisions in group package tour. Anatolia [online]. 2007, 18(1), p. 23-42. ISSN 1303-2917, eISSN 2156-6909. Available from: https://doi.org/10.1080/13032 917.2007.9687034

[58] KANTAWATEERA, K., NAIPINIT, A., SAKOLNAKORN, T. P. N., KROEKSAKUL, P. Tourist transportation problems and guidelines for developing the tourism industry in Khon Kaen, Thailand. Asian Social Science [online]. 2015, 11(2), p. 89-95. ISSN 1911-2017, eISSN 1911-2025. Available from: http://dx.doi.org/10.5539/ass. v11n2p89

[59] REILLY, J., WILLIAMS, P., HAIDER, W. Moving towards more eco-efficient tourist transportation to a resort destination: The case of Whistler, British Columbia. Research in Transportation Economics [online]. 2010, 26(1), p. 66-73. ISSN 0739-8859. Available from: https://doi.org/10.1016/j.retrec.2009.10.009

[60] SUNG, H. H., MORRISON, A. M., HONG, G. S., O'LEARY, J. T. The effects of household and trip characteristics on trip types: A consumer behavioral approach for segmenting the US domestic leisure travel market. Journal of Hospitality \& Tourism Research [online]. 2001, 25(1), p. 46-68. ISSN 1096-3480, eISSN 1557-7554. Available from: https://doi.org/10.1177\%2F109634800102500105 